\title{
Question of the "Monastery of Saint-Naoum", Referring to the Advisory Opinion of the Permanent Court of International Justice
}

\author{
Bledar Komina
}

bledar.komini@cit.edu.al

\author{
Doi:10.5901/ajis.2015.v4n3s1p354
}

\section{Abstract}

\begin{abstract}
One of the most important issues for the Albanian country in the period 1922-1925 has been that of the north and north-east frontier with the Kingdom of Serbs, Croats and Slovenes at the Monastery of Saint Naoum. Referring to the historical facts, the area of St. Naoum was occupied by Serbian troops in 1913. During World War I, they were forced to flee from there (1917). During the period when Commission (of delimitation) had visited the monastery they found there, only two priests, one of whom spoke English, the other Serbo-Croatian. From a geographic standpoint monastery had no particular value, while in terms of religious side he had a lot of great importance for all surrounding regions making up for them a religious pilgrimage site. The problem that had arisen during the fieldwork of Delimitation Commission stood on the fact that the Protocol of London of 1913 expressly stated that "up to the Monastery of Saint Naoum", thus leaving unclear that the word "until" will include or leave abroad it. This problem was brought to the attention of the Conference by a note of September 27th, 1922, from the British Embassy, through which it asked the Delimitation Commission to furnish all the information which might assist the Conference in reaching a decision. The issue spanned a period of several years and took importance because Albanian politics tried to save the limits set in 1913 by the Conference of Ambassadors in London, as well as not to create to the neighboring countries the opportunity to extend their hand to distract from "existing Albania" even a single inch of land. However, the happenings will take different shades because they were held in difficult years of turbulence in Albania and will begin to receive solution only when King Zog returns to power with help of Serbia in December 1924.
\end{abstract}

Keywords: Question of the "Monastery of Saint-Naoum"; Advisory Opinion; Permanent Court of International Justice; Delimitation Committee; King Zog I; League of Nations; Conference of Ambassadors.

One of the most important issues for the Albanian country in the period 1922-1925 has been that of the north and northeast frontier with the Kingdom of Serbs, Croats and Slovenes at the Monastery of Saint Naoum. The issue spanned a period of several years and took importance because Albanian politics tried to save the limits set in 1913 by the Conference of Ambassadors in London, as well as not to create to the neighboring countries the opportunity to extend their hand to distract from "existing Albania" even a single inch of land. However, the happenings will take different shades because they were held in difficult years of turbulence in Albania and will begin to receive solution only when King Zog returns to power with help of Serbia in December 1924.

On June $5^{\text {th }}, 1924$, from Paris, Poincare on behalf of the Conference of Ambassadors addressed to the Secretary General of the League of Nations, emphasizing that according to the support of the Resolution adopted by the Conference of Ambassadors on June 4, 1924, is required by the League that at the next meeting to take in consideration the question submitted as follows:

"Have the Principal Powers, by the Decision of the Conference of Ambassadors dated December 6th, 1922, completely fulfilled in the matter of the Serbian-Albanian Frontier at the Monastery of Saint-Naoum the mission which, as stated by the Assembly of the League of Nations on October 3rd, 1921, it was incumbent upon them to undertake? Should the League of Nations consider that the Conference has not completely fulfilled its mission, what solution should be adopted as regards the question of the Serbo-Albanian Frontier at Saint-Naoum?" (1)

A week later, on June 12, 1924, the League of Nations issued a clarifying statement for the discussions on the issue of St. Naoum at the Conference of Ambassadors. According to the statement ("Note on the Deliberations of the Conference of the Ambassadors Concerning the Allocation of the Monastery of St. Naoum"), the decision of the Conference of Ambassadors, dated November $9^{\text {th }}, 1921$, after confirming the setting of Albania borderlines based on the decision of the Conference of Ambassadors, 1913 in London, stated that the Delimitation Commission that will go on the ground was instructed to take into account in its work all geographical and economic interests of both countries. The aim 
of the commission was to determine exactly the border between the two countries by visiting the line defined by the Conference on the map. The line was made up of four areas or regions:

(a) The region north-east of Scutari;

(b) The region to the west and south of Prizrend;

(c) The region to the west and south-east of Dibra;

(d) The region of Lim, (2)

Based on this visit, it was decided that: the area of Lin to pass to Albania to facilitate communication between the regions and more specifically between Elbasan and Korça along the shore of Lake Ohrid. Given this, no concrete definition was made for the monastery St. Naoum, whose location was in furthest area of the Ohrid Lake, at its southern coast. Conference believes that the definition of this southern province was set at the London Conference in 1913, this was the reason that St. Naoum was not discussed and was never taken for granted the fact that it belonged to Albania. On February $1^{\text {st }}, 1922$, based on communication between the League of Nations and the Delimitation Commission Conference made the decision as follow:

3. To instruct the Delimitation Commission to define on the ground the Serbo-Albanian and Greco-Albanian frontiers fixed by the Conference of London in 1913 up to the actual point at which the work embodied in the Protocol of Florence was begun;

4. To instruct the Technical Geographical Committee to determine a neutral zone from Lim (Lin) up to the point referred' to in paragraph II/1 above." (3)

Moreover, the Protocol of London of 1913, defining the Albanian frontier, is worded as follows:

From north to south:

". . . Thence it shall follow the ridge of Mount Korab, leaving to Albania the district of the 1ower Dibra and outside Albania the district of Reka. Leaving this ridge slightly to lie north of the valley of the Dibra, which shall remain outside Albania, the frontier shall extend to the Black Drina, whose course it shall follow up to the village of Loukovo, whence, passing along the main ridges separating the basin of the Drina from that of the Ghkoumbi and leaving Strouga outside Albania, it shall reach the shores of the Lake of Ochrida in the neighborhood of the village of Lim." (4)

Then from south to the north:

"The shores up to Phtelia, including the Island of Sasseno, the region north of the Greek line, and the former Casa of Koritza, together with the western and southern shores of the Lake of Ochrida, extending from the village of Lim up to the Monastery of Svet-Naoum, shall form part: of Albania." (5)

Referring to the historical facts, the area of St. Naoum was occupied by Serbian troops in 1913. During World War I, they were forced to flee from there (1917). During the period when Commission (of delimitation) had visited the monastery they found there, only two priests, one of whom spoke English, the other Serbo-Croatian. From a geographic standpoint monastery had no particular value, while in terms of religious side he had a lot of great importance for all surrounding regions making up for them a religious pilgrimage site. The problem that had arisen during the fieldwork of Delimitation Commission stood on the fact that the Protocol of London of 1913 expressly stated that "up to the Monastery of Saint Naoum", thus leaving unclear that the word "until" will include or leave abroad it. This problem was brought to the attention of the Conference by a note of September 27th 1922 , from the British Embassy, through which it asked the Delimitation Commission to furnish all the information which might assist the Conference in reaching a decision. Required information and opinions were sent to the Conference in a letter dated November $5^{\text {th }}, 1922$. While a more detailed opinion of the Albanian Commissionaire dated November 30th, 1922, after the Conference had taken its decision. (6)

The British Commissioner, after some hesitation, interpreted the Protocol of London as assigning Saint-Naoum to Serbia; but from an ethnical, geographical and strategic point of view he considered that Saint-Naoum should be left to Albania. The French and Italian Commissioners were in favor of assigning the monastery to Albania. The Commissioners of the countries directly concerned naturally differed in their opinions. With the exception of the opinion of the Albanian Commissioner, none of the documents laid before the Conference drew attention to the moral and religious interests, which would be affected by the decision about to be taken. (7)

It was, moreover, difficult to determine with any certainty the intentions of the authors of the 1913 Protocol. No regular minutes were kept of the Conference of London, nor are there in existence any contemporary official maps showing the tracing agreed upon by the Ambassadors. Subsequent examination of the documents concerning the Conference of 1913 has not made it possible to-establish the intentions of the Conference. Review of documents related to the 1913 Conference did not create any possibility to the Conference of Ambassadors to take a decision. In these 
circumstances, considering that London Protocol could be interpreted in different ways and the opinion that the opinion of Delimitation Commission were very favorable for the granting of this monastery to Albania, Conference decided on December 6,1922 , that the monastery eventually must be passed to the Albanian state. This decision was officially communicated to the two governments in December 23, 1923. It was communicated even to the Delimitation Commission to implement it on the ground. (8)

In the letter of December 23, 1923, in which Poincare addressed the Albanian government, was stated that: "By the letter of November $25^{\text {th }}, 1922$, you are informed that the Conference of Ambassadors was in favor of determining the border of St. Naoum, situated on the southern shore of Ohrid Lake to the Albania. I have the honor to inform you that the Conference of Ambassadors decided to leave the Monastery of St. Naoum to the Albanian state. This decision will be implemented in Albania when the border between the Kingdom of Serbs, Croats and Slovenes will be placed on the ground by the Delimitation Commission ... ". (9) The second letter was addressed to Serbian minister in Paris, Spalaikovich in which Poincare wrote that "London Protocol of 1913 specifies that" the western and southern cost of Ohrid Lake, the area that stretches from the village of Lim to the Monastery of Saint Naoum it will be part of the Albanian state ". This text does not clearly indicate whether the monastery will be part of one or another state. For this reason the task was addressed to the Conference of Ambassadors. I have the honor to inform you that the Conference taking into account the opinion of the Delimitation Commission on the ground, decided to pass the Monastery to the Albanian state." (10)

But despite the announcement, no formal decision was taken by the Conference of Ambassadors to confirm the final proposal given by members of the Delimitation Commission. In this situation, when lacking a formal decision, Belgrade through a note dated April $6^{\text {th }} 1923$, filed before the Conference a series of arguments on the issue of SerboAlbanian border. Some of the facts given were directly connected with the issue of the border between the two countries in St. Naoum and based on ethnic and moral arguments sought to review the decision of December $6^{\text {th }} 1922$. Belgrade during this period tried to artifacts new documents and materials to argue that St. Naoum was never discussed by the Conference of London to be given to Albania, but rather the purpose of the committee that time was give the Monastery to Serbia. In the same spirit was presented even the note of June $28^{\text {th }} 1923$ to the Conference by Belgrade. (11)

The Albanian Government responded to this attempts of Belgrade by two letters addressed to the Conference, the first dated June $20^{\text {th }} 1923$, while the second is dated March $25^{\text {th }} 1924$. According to the first letter of June $28^{\text {th }}$, it bears the signature of J. Dino charge d'affaires in Paris and lays before the Conference of Ambassadors numerous facts and arguments that changing the borders although it remains a long-standing desire of Belgrade it cannot be contrary to the decisions of November $9^{\text {th }} 1921$ and December 1922. Although the Albanian state had sanctioned a territorial invasion by the northern neighbors, never has formally requested to return Albanian territory remaining under the Kingdom of Serbs, Croatian and Slovenes. So even though the town of Dibra a vital hub of the Albanian population remained abroad, severing all ties of this region to those around her, it did not encourage the government of Tirana to submit arguments and require international bodies to join her, despite the desire for unity was great. He also stated that: "For this reason, I have the honor to present to your attention that my Government cannot believe that the Conference of Ambassadors is ready to agree to review the borders... and to reverse a decision that has already received about borders". (12) While J. Dino in a second letter dated March 25 ${ }^{\text {th }} 1924$, addressing to the President of the Conference wrote that "these days, in all major cities of the country began protests and they want that no part of the Albanian territory secede. Nowadays Albania doesn't represent an ethnic country and therefore you have to understand that these feelings that rise in people show that they still has not forgotten the dismemberment of Albanian-populated territories which were given neighboring countries". (13)

On March 27 th 1924, the Legal Committee expressed his opinion. In his opinion, it was clear that there are some facts that must be taken into account and one of these facts was the agreement between Italy and Austro-Hungarian government (on April 22, 1913), requesting that St. Naoum must be given not to the Albania but to Serbia. In addition, the final protocol of August 1913 stated that the Delimitation Committee that will go in the field should take into account all proposals made between Italy and Austria-Hungary in connection with the Albanian border. This - according to the Legal Committee, - gave a great value to the agreement between the two countries (Italy and Austria-Hungary) that St. Naoum was not part of the Albanian state. (14) Immediately after these facts emerged recently, on April $14^{\text {th }} 1924$, the British government through a memorandum expressed that London doesn't have any doubt concerning the will of the participants at the Conference of 1913, nor the decision of 1922 that St. Naoum could be part of Albania. British Government in the memorandum added that both Albania and Yugoslavia were unable to reject the decision taken on December $6^{\text {th }}, 1922$, because in 1921, this decision was taken by the Assembly of the League of Nations that accepted the resolution regarding the determination of the line border between the two countries. London also emphasis the fact 
that the decision of December $6^{\text {th }}$ was communicated to both governments and none of them had refused.

However, French government through the delegates to the Commission continued to support the idea that the case should be rerun again and it needed the commitment of other international institutions like the International Court of Justice. In this line, London reacted immediately (on May 19th 1924 ), by supporting the French idea that it would be better for the case to engage the International Court, to whom they can address the issue for an advisory opinion. (15) In these conditions the issue was presented to the Conference of Ambassadors on June $17^{\text {th }} 1924$, to give its opinion on the issue of the Albania - Yugoslavia borders in the Monastery of St. Naoum. According to the resolution of the same date (June $17^{\text {th }}$ ), despite the decision of December $6^{\text {th }} 1922$ of the Conference of Ambassadors stated that have been many contestations by the Yugoslav party about how they solved this problem. According to the resolution the question was presented as follows: "Have the Principal, Allied Powers, by the decision of the Conference of Ambassadors of December $6^{\text {th }}, 1922$, exhausted, in regard to the frontier between Albania and the Kingdom of the Serbs, Croats and Slovenes at the Monastery of Saint-Naoum, the mission, such as it has been recognized by the interested Parties, which is contemplated by a unanimous Resolution of the Assembly of the League of Nations in October, 1921?" (16)

On June $17^{\text {th }} 1924$ the Secretary General of the League of Nations, Eric Drummond, addressed the case for an Advisory Opinion (Advisory Opinion) to the International Court of Justice (in Hague). (17) In the letter was stated that: "The Secretary-General of the League of Nations, in pursuance of the Council Resolution of June $17^{\text {th }}, 1924$, and in virtue of the authorization given by the Council, has the honor to submit to the Permanent Court of International Justice an application requesting the Court, in accordance with Article 14 of the Covenant, to give an advisory opinion to the Council on the question which has been referred to the Court by the Resolution of June $17^{\text {th }}, 1924$. The Secretary-General will be prepared to furnish any assistance, which the Court may require in the examination of the question, and will, if necessary, arrange to be represented before the Court." (18)

On July 23, 1924 at the Peace Palace in Hague was held the fourth public meeting (part of the fifth session) in connection with the Case of St. Naoum. The meeting was headed by President Loder, while other participants were Deputy President Weiss, and the other members: Lord Finlay, Nyholm, Moore, De Bustamante, Altamira, Oda, Anzilotti, Huber and Pessoa. As secretary of the group of judges was Mr. Hammarskjold. (19) Then session continued with the reading of the case of St. Naum by the secretary. He began reading by giving a historical overview of the issue, which departed from the decision dated December $6^{\text {th }}, 1922$, of the Conference of Ambassadors, which had decided that the Monastery of St. Naoum must remain to the Albanian state. After reading the case by the Secretary, President Loder said that on June $19^{\text {th }}, 1924$, he had received a request from the League of Nations, which require by the Court to express its opinion on the matter. The Albanian government was represented at these meetings by Mr. Mehmet Konica ambassador in London and Paris, B. Blinishti and international law professor Gilbert Gidel. At the other hand Yugoslav party was represented in court by its ambassador to Paris Mr. H. E. Spalaikovitch. (20)

In the annual report of the Court was stated that on October $3^{\text {rd }} 1924$, the Council of the League of Nations in the presence of representatives from Albania and those from the Kingdom of Serbs, Croats and Slovenes, decided to communicate the Ambassadors the opinion given by the Court on September $4^{\text {th }} 1924$. A year later on April 27th 1925 , the Conference in Paris communicated to the representatives of the two countries concerned, that St. Naoum should remain within Albanian borders.

On May 6, 1925, the Representative Minister of the Kingdom of Serbs, Croats and Slovenes in Paris sent to the President of the Conference of Ambassadors a note according to which, Belgrade was ready to make progress in the talks, after the stalemate of the question (after the decision of September $4^{\text {th }}$ 1924). Belgrade claimed to have new evidences, which wanted to make available to the Conference and the Court. These facts consisted of a circular letter dated September 30th 1913, that Count Berchtold distributed to the Austro-Hungarian ambassador in Berlin, Paris, Rome and St. Petersburg. In this paper were given new details on the issue of Serb-Albanian border. According to the letter, the border would follow the western shore of Lake Ohrid, near the village of Lin, going right at the lake's southern shore, to the Monastery of St. Naum who will remain abroad. (21) International Court after the presentation of this fact by the Yugoslav party, mentioned for the first time, asked the two delegations to find a common language and amicable resolution of the case. The Court advised the parties to continue negotiations by that spirit.

On June $28^{\text {th }} 1925$, representatives of the two countries said they had reached a bilateral compromise solution, concluding that St. Naoum monastery will eventually pass to Yugoslavia, while the village of Peshkopi will pass to the Albanian state. By a decision dated August $6^{\text {th }}$ 1925, the Conference of Ambassadors approved the ratification of the two delegations signed on June $28^{\text {th }}$. On November $11^{\text {th }} 1925$ the governments of both countries' (respective parliaments) ratified the agreement signed between the two delegations. (22) President of the Conference of Ambassadors reviewed the agreement and gave its approval eventually ending the border issue between Albania and Yugoslavia. 


\section{References}

Acts and Documents Relating to Judgments and Advisory Opinions Given by the Court, Question of the Monastery of Saint-Naoum (Albanian Frontier), Leyden: Series C, Documents relating to advisory opinion No. 9, No. 5, Part III - Other Documents, Publications of the Permanent Court of International Justice, p. 70. ("The Conference of Ambassadors to the Secretary General of the League of Nations").

Ibid, p. 70-71.

Acts and Documents Relating..., Part III, op. cit. p. 71. "League of Nations: Note on the Deliberations of the Conference of Ambassadors".

Ibid, p. 72.

Ibid, p. 72.

Ibid, p. 72.

Acts and Documents Relating..., "League of Nations: Note on the Deliberations of the Conference of Ambassadors Concerning the Allocation of the Monastery of Saint Naoum". Part III, op. cit., p. 73.

Ibid, p. 73. For more check: AMPJSH (Albanian Ministry of Foreign Affairs Archive). F. (Fund) 151, V. (Year) 1922, D. (File) 43, Fl. (Page) 9 .

Acts and Documents Relating..., "Le Président de la Conférence des Ambassadeurs au Président: de la Delégation Albanaise a Paris". Part III, op. cit., p. 101.

Acts and Documents Relating..., "Le President de la Conférence des Ambassadeurs A S. Hxc, M. Spalaikovitch, Ministre du Royaume des Serbes, Croates et Slovènes a Paris". Part III, op. cit., p. 101.

Acts and Documents Relating..., "League of Nations: Note on the Deliberations of the Conference of Ambassadors Concerning the Allocation of the Monastery of Saint Naoum". Part III, op. cit., p. 73.

Ibid. p. 73.

Acts and Documents Relating..., "Le Charge d'Affaires d'Albanie a Paris au President de la Conférence des Ambassadeurs", 25 mars 1924, Part III, op. cit., pp. 113-114.

Acts and Documents Relating..., "League of Nations: Note on the Deliberations of the Conference of Ambassadors Concerning the Allocation of the Monastery of Saint Naoum". Part III, op. cit., pp. 74-75.

Ibid, p. 75-76.

Acts and Documents Relating..., "Resolution of the Council of the League of Nations, Adopted June 17th 1924", Part III, op. cit., p. 68.

Acts and Documents Relating..., "Request for Advisory Opinion". From League of Nations to the Permanent Court of International Justice. Part III, op. cit., p. 67.

Ibid, p. 67.

Acts and Documents Relating to Judgments and Advisory Opinions Given by the Court, Question of the Monastery of Saint-Naoum (Albanian Frontier), Leyden: Series C, Documents relating to advisory opinion No. 9, Public Sittings, No. 5, Part I, Publications of the Permanent Court of International Justice, p. 8.

AMPJSH. (Albanian Ministry of Foreign Affairs Archive) F. (Fund) 151, V. (Year) 1924, D. (File) 131, Fl. (Page) 135-137. Check also: Acts and Documents Relating..., Part I, op. cit. p. 9.

Annual Report of the Permanent Court of International Justice, Leyden: Second Annual Report, Series E, No. 2, A. W. SIJTHOFF'S Publishing Company, June $15^{\text {th }} 1925$ - June $15^{\text {th }} 1926$, pp. 137-138.

Ibid. p. 138. 